\title{
Q. $\mathrm{PCB}$ の分析法について教えてくださ い（一読者）
}

\section{第 8 回夏期セミナ一報告}

発光部会光源研究会では第 8 回夏期セミナー（分光研 究 21 巻 $2 \sim 3$ 号) を 47 年 8 月 7 日〜 10日の 4 日間長野県 大町市扇沢で開催しました，参加者は約40名で，初参加 の方も例年より多く，盛沇でした．セミナーに刘する意 見を求めるため，また，48年度は10年目にあたることか ら, 運営委員会は参加者にアンケートを为原いしました。

内容は "第8 回セミナーについて" (a.テーマ, b. 内 容, c. 講師の人選, d. 場所・会場, e. 参加费, f. 日数, g. 時間割) と "今後のセミナーについて" (a. 今後の続 否，b. 48 年度に開催するとしたらイイ、テーマ,ロ。 内容・濖師，八. 場所, 二. 日数・時間割, ホ. その他 の意見）でした３0名に配布し22名より解答が集まりま した。.以下に簡単に紹介しますั.

"第8回セミナーについででは，参加费の点で意見 が分かれましたが（高い.9, 適当. 11，安い.2)， と の他の項ではほとんど全員が適当であったひじょらに 参考になったという回答でした. "今後のセミナーにつ いででは, 全員がセミナーの継続を希望して扎られ, 主催者の労をねぎらっての解答の感もしますが，夏期セ ミナーへの期待が感じられます. 場所については東京に 近い凉しい高原, 日数・時間割については従来通りとい う意見が多数を占めました，その他の項目では多様な御 意見，御希望がありました．以下にその内の幾つかを列 举します.

テーマについて：分光分析の将来性，原子吸光・蛍光， 分光分析用光源の理論之応用, 試料の処理法, 運営委員 会はそのためにある，基整的なるのと最近の研究に分け る等，竹師について：非常識的な発想のできる人，隣接 分野の人等，その他の意見：回を重ねたのでまとめる亦 を考える，主題に関係した研究報告，共同研究調查を中 心とした討論も加える，若い人が参加できるように䜋習 会的要菜を加える, 参加者を增す等.

解答を下さった全員が夏期セミナーに期待しており, その内容, 運営について参考になる御意見, 御希望を寄 せて下さいましたので，できる限りの烃力を重ね御期待 にそう運営をしていきたいと思っていますे。

なお、第 8 回夏期セミナーのテキストは残部がありま すので，本部にお申し込み下されば有料配布します。

(発光部会・光源研究会・運営委員会)
A. PCB (Poly chlorinated biphenyls) は 2 ケのフェ ニル基に塩素が 1〜10 結合し，それぞれに異性体を有与 る一量の化合物で, 不燃性, 優秀な電爻絶緣性, 物理的 ・化学的安定性など特異な性質を有するため, 絶緣油, 蓺媒体，染料用溶剂・可塑剤などに利用されていた。 し かし上述の特性および生物分解性の久除などのために， 環境污染などの重大な問題を惹起した． PCB の分析は， 異性体の混合物であること，標準物質が得がたいこと， 他物質による妨富が大きいこと，試料が一般的に複雑な マトリックスで構成されていることなど困難な問題が非 常に多い.

通常，分析は，1）試料よりの抽出，2）抽出物の精製 および有機塩素系農薬からの分離と濃縮，3) ECD 型ガ スクロによる測定，4） PCB の塩素化による十塩化ビフ エニルとしての分析，以上のような順序で行なわれる． 実際には甚だ面倒な方法で， PCB が有機塩素系農薬と 同様に脂溶性であるため, n一ヘキサンで抽出するが, 抽 出物中にグリセライド，その他の脂質，有機塩素系農薬 などが PCB と共に含まれるので，抽出物を $1 \mathrm{~N}-\mathrm{KOH}$ エタノール溶液で一時間程劣沸して脂質を禴化し，ざら に n一ヘキサンで再抽出する。この再抽出物をシリカゲ ルカラムクロマトで, 有機塩素系農薬と分離し, n一へキ サン溶液を濃縮して， $\mathrm{ECD}$ 型ガスクロにかける。ここ で用いる Electron Capture 㭥出器はハロゲン，イオ ウ，チッ素などを含む化合物の検出に有効である。この 方法は $\mathrm{ppb}$ 程度の濃度まで測定が可能であるので, ク ロマトグラフのピークの確認にはことに慎重を期せねば ならない.これは他に同程度の感度で cross check す る手段がないからである.最後に PCB に関する文献の らち，総説的なるのを揭げるが，その他，学術誌を参照 ざれたい.

1) Jensen, S.; New Scientist, 32, (1966) 612.

2) Risebrough, R.W., et al.; Nature, 220, (1968) 1098.

3）塚元久雄他; 福岡医学雑誌, $60,(1969) 6$ 号, 62, (1971) 1 号.

4）立川凉；公害と対策，7, (1971) 5 号，416.

5) Fishbien, L.; J. Chromalography, 68, (1972) 345.

6）米国政府；公書と刘策，8，(1972）10１1号.

（編集委員会） 